\title{
FREE-LIVING AMOEBAE (FLA): DETECTION, MORPHOLOGICAL AND MOLECULAR IDENTIFICATION OF ACANTHAMOEBA GENUS IN THE HYDRAULIC SYSTEM OF AN HAEMODIALYSIS UNIT IN TUNISIA
}

\author{
DENDANA F.*, SELLAMI H.*, JARRAYA F.**, SELLAMI A.*, MAKNI F.*, CHEIKHROUHOU F.*, \\ HACHICHA J.** \& AYADI A.*
}

\section{Summary:}

The free-living amoebae (FLA) are ubiquitous and opportunistic protozoa. They can induce human and animal diseases. The aim of our study was to detect the FLA and Acanthamoeba genus in the hydraulic system of an hemodialysis unit. It was a prospective study of 46 water samples. The first collect (23) was before cleaning and after the haemodialysis sessions and the second (23) after cleaning and before the hemodialysis sessions. Results: the morphological study enabled us to detect morphotypic diversity. The predominant morphotypes were the acanthopodial forms (29\%). At the entrance of hemodialysis unit there were acanthopodial (44 \%) and monotactic (25\%) forms; at the outlet, acanthopodial and fan-shaped forms (25\% each). In addition, Acanthamoeba genus was present in $39 \%$ ( $1^{\text {st }}$ collect) and $18 \%$ ( $2^{\text {nd }}$ collect). The amplification of the FLA 185 rDNA gene was negative in only one sample localized in the last stage of water treatment unit (WTU). The amplification of the 18S rDNA (ASA.A1)

Acanthamoeba gene was positive in 15 samples. Conclusions: we noted that, in the hemodialysis unit, the purification techniques used in the WTU were effective, but there is a problem of water stagnation in the drain, which constitutes an appropriate condition for the biofilms formation. It is then necessary to use a filter with a low porosity $(0.2 \mu \mathrm{m})$ at the entrance of the hemodialysis unit and if possible to change the drain

KEY WORDS : free-living amoeba, hemodialysis, Acanthamoeba, morphology identification, PCR.
Résumé : LES AMIBES LIBRES : DÉTECTION, IDENTIFICATION MORPHOLOGIQUE ET MOLÉCULAIRE DU GENRE ACANTHAMOEBA DANS LES CIRCUITS HYDRIQUES DE L'UNITÉ D'HÉMODIALYSE DE TUNISIE

Les amibes libres (AL) sont des protozoaires largement répartis dans la nature. Elles peuvent être pathogènes pour l'homme ou l'animal. L'objectif de notre étude a été de détecter les AL et le genre Acanthamoeba au niveau du circuit hydrique d'une unité $d$ 'hémodialyse. Cette étude prospective a porté sur 46 échantillons d'eau. La première collecte (23) a été réalisée après la séance d'hémodialyse et avant le nettoyage des appareils; la seconde (23) avant la séance d'hémodialyse et après le nettoyage des appareils. Résultats : l'étude morphologique nous a permis de détecter une diversité morphotypique avec prédominance du morphotype acanthopodial (29\%). À l'entrée des appareils d'hémodialyse, les morphotypes ont été dominés par acanthopodial (44\%) et monotactique (25\%); à la sortie, par acanthopodial (25\%) et fan-shaped (25\%). Par ailleurs, le genre Acanthamoeba a été présent dans $39 \%$ des cas ( 7 ère collecte) et $18 \%$ des cas (2ème collecte). L'amplification du gène 18S rDNA des AL n'a été négative que pour un seul échantillon.

L'amplification du gène 18S rDNA spécifique d'Acanthamoeba a été positive pour 15 échantillons. Conclusion : nous avons noté que les techniques de purifications utilisées dans cette unité de traitement ont été efficaces, mais il y a un problème de stagnation d'eau dans la canalisation, favorisant ainsi la formation des biofilms. Il est donc nécessaire d'utiliser un filtre dont la porosité est inférieure à $0.2 \mu \mathrm{m}$ à l'entrée des appareils d'hémodialyse et éventuellement de renouveler la canalisation.

MOTS CLÉS : amibe libre, hémodialyse, Acanthamoeba, identification morphologique, PCR.

\section{INTRODUCTION}

F ree living amoebae belonging to the genera Acanthamoeba, Balamuthia, and Naegleria are responsible for opportunistic and non-opportunistic infections in humans and other animals (Martinez \& Visvesvara, 1997). These organisms are distributed worldwide and have been isolated from soil, dust, air, seawater, swimming pools, sewage, dental treatment units, dialysis units, eyewash stations and contact lenses

\footnotetext{
* Fungal and parasitic molecular biology laboratory, School of Medicine Sfax, Tunisia.

*** Nephrology Ward, Hedi Chaker Hospital, Sfax, Tunisia.

Correspondence: Ali Ayadi.

Tel./Fax:0021674247130 - E-mail: ali.ayadi@rns.tn
}

(Casemore, 1977; Rivera et al., 1987; Mergeryan, 1991; Paszko-Kolva et al., 1991; Szenasi et al., 1998; Michel et al., 2001; Lorenzo-Morales et al., 2006, 2007). Acanthamoeba spp. have also been isolated from vegetation, animals including fish, amphibian, reptiles and mammals (Sesma et al., 1989; Dykova et al., 1999; Walochnik et al., 1999), infected brain and lung tissue, immunosuppressed patients, and from corneal tissue of patients with Acanthamoeba keratitis (Lalitha et al., 1985; Martinez \& Visvesvara, 1997; Ndiaye et al., 2005; Ben Salah et al., 2007).

The aim of our investigation was to detect and characterize by morphological and molecular means the free living amoeba and the Acanthamoeba genus from the hydraulic system of the hemodialysis and treatment water unit of Sfax University Hospital, Tunisia. 


\section{MATERIALS AND METHODS}

\section{SOURCES OF AMOEBIC ISOLATES AND SAMPLES COLLECT}

Timation $\mathrm{t}$ was a prospective study dealing with 46 water samples collected during October and December 2005 from hemodialysis units and WTU. The first collect (23) was before cleaning and after hemodialysis sessions (11 at the entrance of dialyser and 12 at the outlet). The second collect (23) was after cleaning and before hemodialysis sessions (eight at the entrance, eight at the outlet, and seven from the WTU).

\section{SAmPle COlLeCtion AND CUlTuRe OF FLA}

$500 \mathrm{ml}$ of each water sample was filtered through a cellulose acetate filter $0.45 \mu \mathrm{m}$ diameter under a weak vacuum. Inoculation of about $1 \mathrm{ml}$ of various amoeba suspensions from each filtered sample onto $1.5 \%$ nonnutritive agar plates seeded with heat-killed suspension of E. coli was out for amoeba isolation (Schuster, 2002). Samples were incubated at $25^{\circ} \mathrm{C}$ and examined daily for 7-14 days post-inoculation under a light microscope. The cultures containing fungi were discarded. Sub-cultivation of amoeba isolates was performed every 14 days. Axenic cultures were obtained by transferring a piece of agar containing some amoebae to liquid culture medium PYG slightly modified (Schuster, 2002).

The strain (Linc-AP1) of $A$. polyphaga used was isolated by T.J. Rowbotham, Public Health Laboratory, Leeds, United Kingdom. It was grown at $25^{\circ} \mathrm{C}$ for four days in $25 \mathrm{~cm}^{3}$ culture flasks (Greiner Bio-One, Germany) containing $15 \mathrm{ml}$ of PYG slightly modified medium.

\section{Microscopic EXAMINATION OF AMOEBAE}

Wet mounted and permanently stained smears (trichrome, Giemsa, nuclear read, or ethylene bleu) of amoeba trophozoites and cysts were examined by light microscope at $100 \times, 400 \times$ and $1,000 \times$ magnification. For classification, the Pussard \& Pons (1977) and Page (1988) keys were applied.

\section{EXTRACTION OF NUCLEAR DNA}

The amoeba cells were pelleted (1,000 g) for $10 \mathrm{~min}$ at room temperature and washed three times with phosphate-buffered saline (PBS) pH 7.2. Cell pellets were resuspended in lysis buffer $(50 \mathrm{mM} \mathrm{NaCl}, 10 \mathrm{mM}$ EDTA, $50 \mathrm{mM}$ Tris-HCl, $\mathrm{pH}$ 8) and incubated at $56^{\circ} \mathrm{C}$ for $1 \mathrm{~h}$ with $0.25 \mathrm{mg} / \mathrm{ml}$ proteinase $\mathrm{K}$. The amoeba DNA was purified by phenol-chloroforme method (Lonrenzo-Morales et al., 2005). The DNA was stored at $-20^{\circ} \mathrm{C}$ until used.

\section{PCR AMPLIFICATION}

For molecular identification, two primer pairs were used: an Acanthamoeba-specific PCR including JDP1-
JDP2 primer pair targeting the ASA.S1 sequence on Acanthamoeba $18 \mathrm{~S}$ rDNA gene, and another primer pair in order to confirm the presence of FLA DNA and its quality. This PCR was carried out with forward primer P-FLA-F (5'CGCGGTAATTCCAGCTCCAATAGC3') and reverse primer P-FLA-R (5'CAGGTTAGGTCTCGTTCGTTAAC3') that were targeted at conserved stretches of Acanthamoeba $18 \mathrm{~S}$ rDNA (Tsvetkova et al., 2004). For all PCRs, amplification reactions were performed in a $50 \mu \mathrm{l}$ mixture containing 50 ng DNA, $10 \mu 1$ XXGene buffer, $0.2 \mathrm{mM}$ each of dATP, dGTP, dCTP, and dTTP, and 20 pmol of each primer, 2.5 units of GoTaq DNA polymerase (promega, Madison, USA). The P-FLA-F/P-FLA-R and JDP1/JDP2 PCRs were done in 40 cycles with denaturation $\left(94^{\circ} \mathrm{C}, 30 \mathrm{~s}\right)$, annealing $\left(57^{\circ} \mathrm{C}, 1 \mathrm{~min}\right.$ for FLA, and $63^{\circ} \mathrm{C}$ for JDP) and primer extension $\left(72^{\circ} \mathrm{C}, 1.5 \mathrm{~min}\right)$. After the last cycle, a primer extension was continued for $5 \mathrm{~min}$ at $72^{\circ} \mathrm{C}$. Amplification products from all PCRs were analyzed by electrophoresis through a $1.5 \%$ agarose gel.

\section{RESULTS}

\section{MORPHOLOGICAL STUDY}

The 46 water samples examined from two sampling point (hemodialysis unit and WTU) yielded 45 FLA positive sample. The negative sample was from the last point of the WTU. The predominant morphotype was the acanthopodial (29\%) followed by monotactic form (22\%) (Fig. 1).

In the first collect, all morphotypes were present with rather high frequency except for eruptive morphotype which was rarely detected (4\%) in the first taking away. The acanthopodial morphotype was present in nine of 23 (39 \%) samples.

In the second collect, the majority of morphotypes were present with rather low frequency and absence of eruptive morphotype.

However, in WTU the majority of morphotypes were absent except these three morphotypes: acanthopodial (33 \%), monotactic and dactylopodial (17\% each) (Fig. 2).

The morphotype frequencies varied according to the taking away points (Fig. 3):

- at the entrance: acanthopodial (44\%) followed by monotactic and dactylopodial forms (25\% each);

- at the outlet: acanthopodial and fan-shaped (25\% each).

\section{MOLECUlar STUDY}

- Free living amoebae detection

The DNA sample amplification, after culture, with primers P-FLA-F/P-FLA-R was positive in 45 (97.8 \%) of 46 samples. The negative sample was located in the 

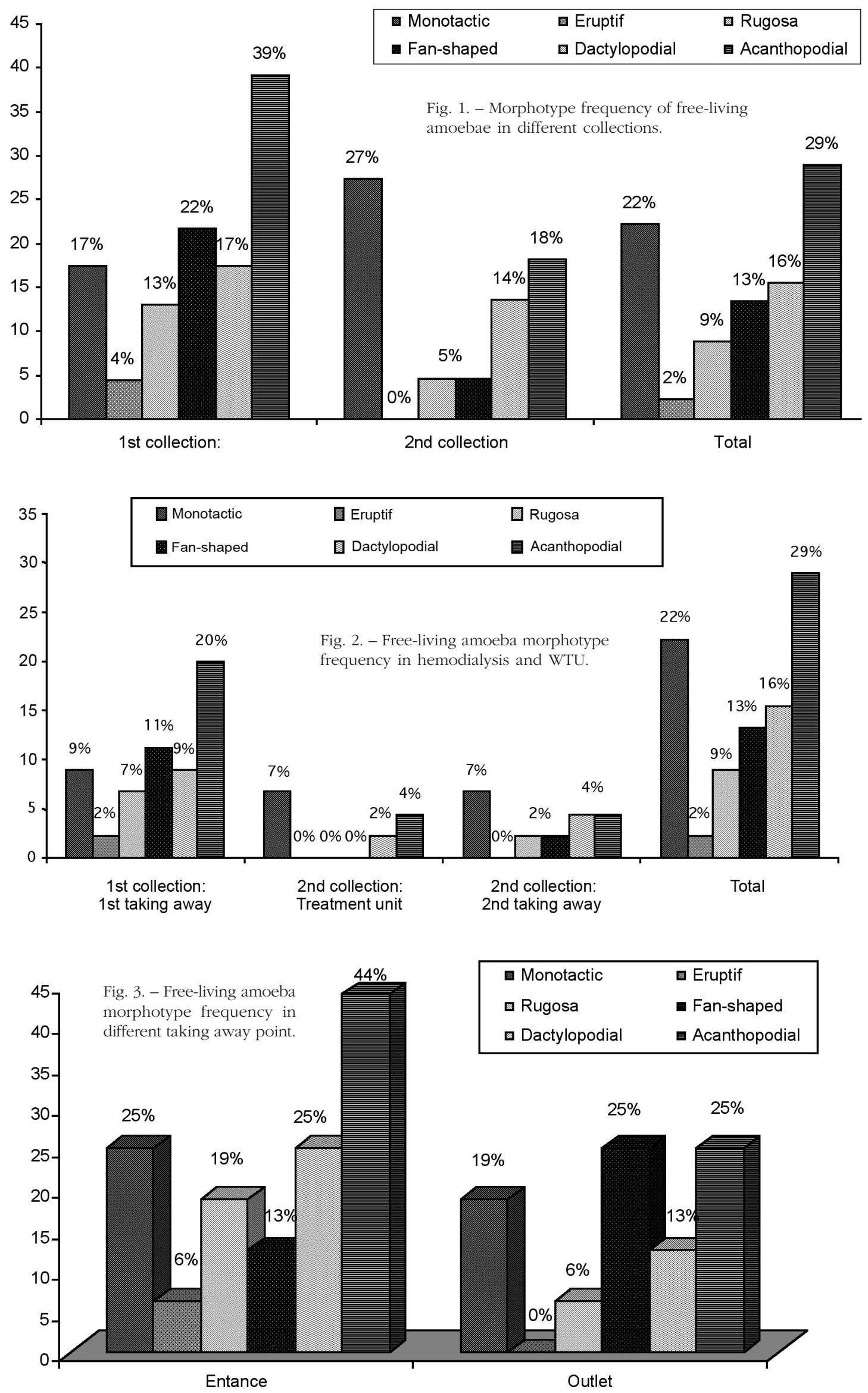


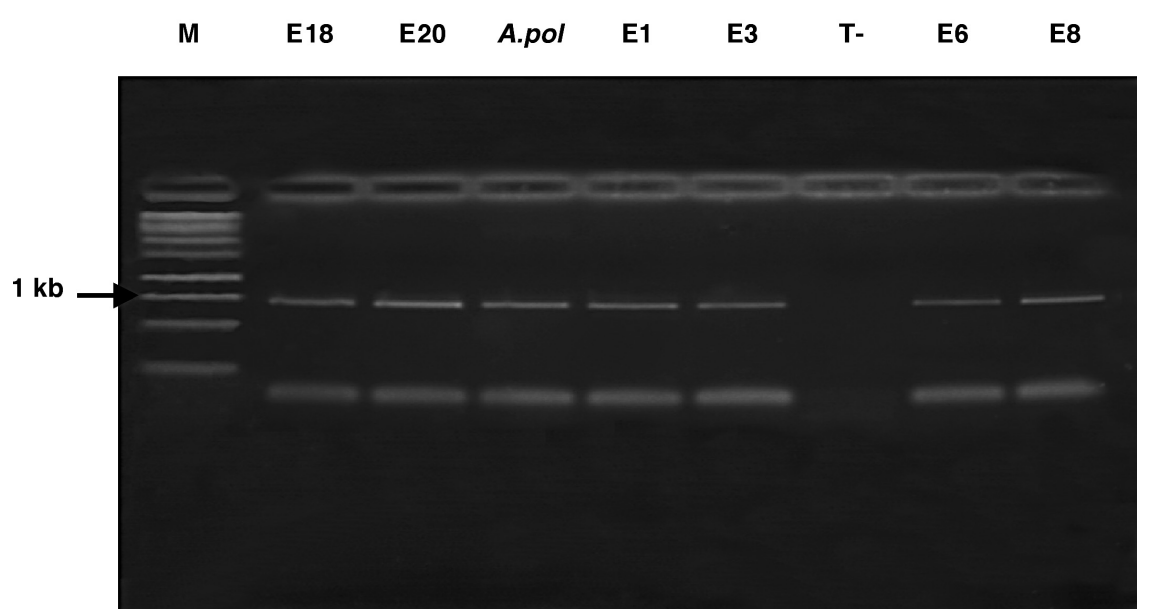

Fig. 4. - PCR amplification using P-FLA F/P-FLA-R primer pair.

M: size marker (1kb DNA ladder); T-: negative control (without DNA); A. pol: A. polyphaga (Linc AP-1); $1^{\text {st }}$ collection samples: entrance: E1, E3, E6, E18 and E20; outlet: E8.

last point of WTU. The result by these primers showed a band of approximately $1 \mathrm{~kb}$ size (Fig. 4).

- Acanthamoeba genus detection

The Acanthamoeba genus was detected in 15 samples among 46: 12 (80 \%) from the first collect, 3 (20\%) from the second.

At the taking away points, Acanthamoeba genus was detected in eight samples at the entrance of hemodialysis apparatuses (53\%), six samples at the outlet ( $40 \%$ ) and only one sample at the WTU (7\%) (after pre-chlorination stage). Amplification by the specific primer of Acanthamoeba genus: (JDP1/JDP2) gave us two bands: (Fig. 5A, B).

A band of approximately $450 \mathrm{bp}$ detected in 14 positive samples among 15, which were distributed as:

- in the first collect: seven samples at the entrance and five samples at the outlet;

- in the second collect: one sample in each level of the taking away: entrance, outlet and WTU.

The second band was approximately $550 \mathrm{bp}$, detected in five samples at the first collect: four samples at the entrance and one at the outlet.

PCR amplification of four samples showed the presence of two bands 450 and 550 bp size (Fig. 5A).

\section{DISCUSSION}

1 o the best of our knowledge, this is the first Tunisian and African study which was devoted to the detection and morphological and molecular identification of the free amoebae and Acanthamoeba genus in the hemodialysis unit and the WTU. In other respects, in the literature few studies were interested with this Acanthamoeba spp. localization (Casemore, 1977).

In African regions, the majority of authors were interested to detect and identify Acanthamoeba species in clinical samples. Recently, some cases of Acanthamoeba keratitis were reported in South Africa (Dini et al.,
2000), in Mali (Quinio et al., 2000) and in Ghana (Leck et al., 2002). A case of meningoencephalitis caused by Acanthamoeba spp. was diagnosed in Dakar (Ndiaye et al., 2005).

The extents to which free living amoebae are present in water sources associated with human activities have been previously studied in Egypt (Mansour et al., 1991; Hamadto et al., 1993; Sadaka et al., 1994; LorenzoMorales et al., 2006) and Morocco (Lorenzo-Morales et al., 2007).

Morphological study enabled us to detect morphotypic diversity. Water samples were collected at different times. We noted a higher frequency variation of the morphotypes during these different taking away. This could be due to the fact that the first taking away was carried out after the hemodialysis session and before the cleaning stage and daily apparatuses disinfection, contrary to the second taking away which was carried out before hemodialysis session and after cleaning stage. Acanthopodial morphotype frequency was higher in the first than the second collect. This variation could be due to the condition and the time realization.

In this study, we were interested in the acanthopodial morphotype including the Acanthamoeba spp. which is pathogenic and frequent in our collections.

Acanthamoeba genus was identified by the nucleotide sequences of the PCR amplifying ASA.S1 region (Schroeder et al., 2001). As previously demonstrated by Schroeder et al. (2001), a 423 to 551 bp Acanthamoeba-specific amplimer ASA.S1 obtained with primers JDP1 and JDP2 contains substantial inter-strain sequence variation, which allows discrimination between several clusters of 18S rDNA genotype (genotypes T1-T15).

The band size of $A$. polyphaga reference strain was $450 \mathrm{pb}$. This same band was detected in our samples. It could be also DNA amplification of other species (A. castellanii or A. hatchetti) classified among the pathogenic species and able to cause infections to humans (Schuster \& Visvesvara, 2004). Tsvetkova N. et al. (2004) found the same band $450 \mathrm{bp}$ in the majority of 

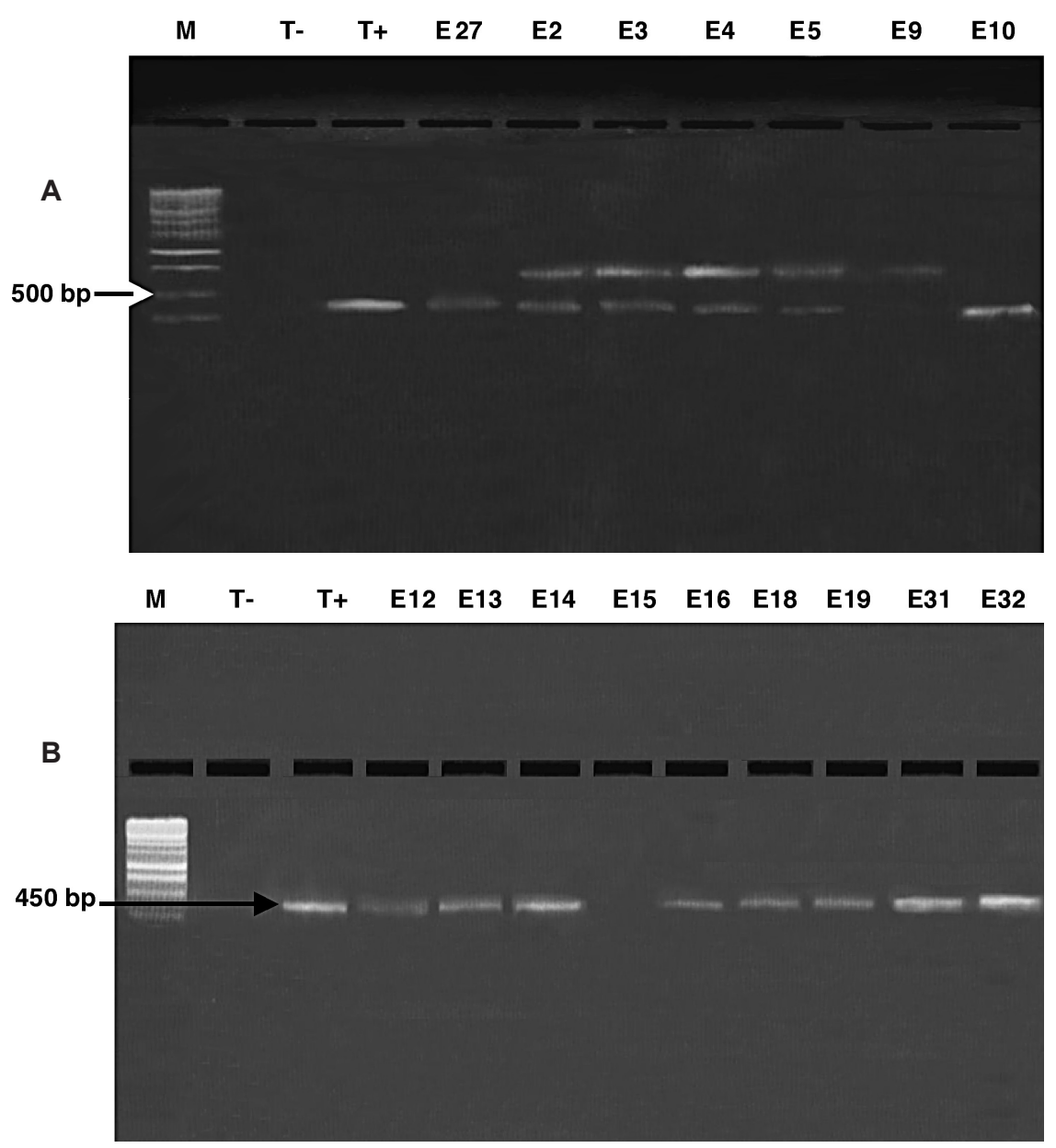

Figs 5A, B. - PCR amplification of ASA.S1 using Acanthamoeba genus-specific primer pair JDP1/JDP2.

M: size markers (1 kb DNA ladder); T-: negative control (without DNA); $\mathrm{T}+$ : Acanthamoeba polyphaga (Linc AP-1); $1^{\text {st }}$ collection samples: E2, E3, E4, E5, E16, E18 and E19: entrance; E9, E10, E12, E13, E14 and E15: outlet; $2^{\text {nd }}$ collection samples: E31: entrance; E32: outlet; E27: treatment unit (pre-chlorination).

samples taken from the environment. They have studied various stocks of Acanthamoeba spp. reference species; they found the following band sizes: $420 \mathrm{bp}$ correspond to $18 \mathrm{~S}$ rDNA genotype T5, $450 \mathrm{bp}$ (genotype T4 and T11), $500 \mathrm{bp}$ (genotype T9), and $550 \mathrm{bp}$ (genotype T7). In our study the species having a band of 550 bp must be corresponding to $18 \mathrm{~S}$ rDNA genotype T7, this species of Acanthamoeba is not pathogenic. The presence of these two bands ( $450 \mathrm{bp}, 550 \mathrm{bp}$ ) in four samples could correspond to an association of two different 185 Acanthamoeba spp.

Water analysis after the last filtration stage (porosity filter $0.2 \mu \mathrm{m}$ ) did not reveal any amoeba. However, water at the entrance of hemodialysis apparatus contained free amoebae and particularly Acanthamoeba genus. Indeed, this treated water crosses a long drain (200 meters) with many bents connecting the WTU to the hemodialysis unit. In this way, water can stagnate and there could be a development of biofilms making then a favorable condition for growth and proliferation of all microbial germs and especially FLA. These last adhere to internal surface water drain and can be rolled up with a viscous layer of polysaccharidic substance (glycocalyx) which protects micro-organisms from the chemical attacks and the desiccation.
This long drain can explain the high frequency of different free amoebae morphotypes at the entrance of hemodialysis apparatuses (acanthopodial and others morphotypes). However, it is important to note that the membrane of the dialyser used is changed for each patient. It is semi permeable and with low permeability then able to retain micro-organisms.

So, the last filtration stage avoids the risk of amoebae passage in blood and the problem of the presence of amoebae is not amoebae systemic infections but that they are carriers of a lot of bacteria and virus which could cross the filter.

It is then important and necessary to have a filter of porosity lower than $0.2 \mu \mathrm{m}$ before the water stage entrance in hemodialysis apparatus and to use a drain as short as possible with no bent.

\section{REFERENCES}

Ben Salah S., Makni F., Cheikrouhou F., Ben Zina Z., Mlik M., FeKi J., Colin J. \& Ayadi A. Acanthamoeba keratitis: about the first two Tunisian cases. Bulletin de la Société de Pathologie Exotique, 2007, 100 (1), 41-42. 
Casemore D.P. Free-living amoebae in home dialysis unit. Lancet, 1977, Ii, 1078.

Dini L.A., Cockinos C., Frean J.A., Niszl I.A. \& Markus M.B. Unusual case of Acanthamoeba polyphaga and Pseudomonas aeruginosa keratitis in a contact lens wearer from Gauteng, South Africa. Journal of Clinical Microbiology, 2000, 38, 826-829.

Dykova I., Lom J., Schroeder-Diedrich J.M., Booton G.C. \& BYERS T.J. Acanthamoeba strains isolated from organs of freshwater fishes. Journal of Parasitology, 1999, 85, 11061113 .

Hamadto H.H., Aufy S.M., el-Hayawan I.A., Saleh M.H. \& Nagaty I.M. Study of free living amoebae in Egypt. Journal of the Egyptian Society of Parasitology, 1993, 23, 631-637.

Lalitha M.K., Anandi V., SRivastava A., Thomas K., Cherian A.M. \& Chandi S.M. Isolation of Acanthamoeba culbertsoni from a patient with meningitis. Journal of Clinical Microbiology, 1985, 21, 666-667.

Leck A.K., Matheson M.M., Hagan M. \& Ackuaku E. Acanthamoeba keratitis in Ghana. British Journal of Ophthalmology, 2002, 86, 1187-1188.

Lorenzo-Morales J., Ortega-Rivas A., Foronda P., Martinez E. \& VAlLaDARS B. Isolation and identification of pathogenic Acanthamoeba strains in Tenerife, Canary Island, Spain, from water sources. Parasitology Research, 2005, 5, 13011302 .

Lorenzo-Morales J., Ortega-Rivas A., Martínez E., Khoubbane M., Artigas P., Periago M.V., Foronda P., Abreu-Acosta N., VAlladares B. \& MAS-Coma S. Acanthamoeba isolates belonging to T1, T2, T3, T4 and T7 genotypes from environmental freshwater samples in the Nile Delta region, Egypt. Acta Tropica, 2006, 100, 63-69.

Lorenzo-Morales J., López-Darias M., Martínez-Carretero E. \& VALLADARES B. Isolation of potentially pathogenic strains of Acanthamoeba in wild squirrels from the Canary Islands and Morocco. Experimental Parasitology, 2007, 117(1), 7479.

Mansour N.S., SaOud A.F., Nashed N.N. \& Youssef F.G. Freshwater amoebae from four aquatic sites in Egypt. Journal of the Egyptian Society of Parasitology, 1991, 21, 15-22.

Martinez A.J. \& Visvesvara G.S. Free-living, amphizoic and opportunistic amebas. Brain Pathology, 1997, 7, 583-598.

MERgERYAN H. The prevalence of Acanthamoeba in the human environment. Reviews of Infectious Diseases, 1991, 13 (Suppl. 5), S390-S391.

Michel R., Muller K.D., \& Hoffmann R. Enlarged Chlamydialike organisms as spontaneous infection of Acanthamoeba castellanii. Parasitology Research, 2001, 87, 248-251.

Ndiaye M., Diop A.G., Dieng Y., Seydi M., Diouf F.S., Diop B.M. \& NDIAYE I.P. A case of meningoencephalitis caused by Acanthamoeba sp. in Dakar. Médecine Tropicale, 2005, 65 (1), 67-68.

Page F.C. A new key to freshwater and soil Gymnamoebae. Freshwater Biological Association, Ambleside, Cumbria, UK, 1988, 122.

PaszKo-KOlva C.Y, Yamamoto H., Shahamat M., SAwyer T.K., YMORRIS G. \& COLWELl R.R. Isolation of amoebae and Pseudomonas and Legionella spp. from eyewash stations. Applied Environmental Microbiology, 1991, 57, 163-167.
Pussard M. \& Pons R. Morphologie de la paroi kystique et taxonomie du genre Acanthamoeba (Protozoa : Amoebida). Protistologica, 1977, 13, 557-598.

Quinio D., Le Flohic A.M., Moalic E. \& Resnikoff S. Acanthamoeba keratitis: search for a healthy carrier in Mali. Médecine Tropicale, 2000, 60 (1), 61-63.

Rivera F., Roy-Ocotla G., Rosas I., Ramirez E., Bonilla P. \& LARES F. Amoebae isolated from the atmosphere of Mexico City and environs. Environmental Research, 1987, 42, 149-154.

Sadaka H.A., el-Nassery S.F., abou Samra L.M. \& Awadalla H.N. Isolation and identification of free-living amoebae from some water sources in Alexandria. Journal of the Egyptian Society of Parasitology, 1994, 24, 247-257.

Schroeder J.M., Booton G.C., Hay J., Niszl I.A., Seal D.V., Markus M.B., Fuerst P.A. \& Byers T.J. Use of subgenic $18 \mathrm{~S}$ ribosomal DNA PCR and sequencing for genus and genotype identification of Acanthamoeba from humans with keratitis and from sewage sludge. Journal of Clincal Microbiology, 2001, 39, 1903-1911.

Sesma Madrigal M.J. \&. Zapatero Ramos L.M. Isolation of freeliving amoebas from the intestinal contents of reptiles. Journal of Parasitology, 1989, 75, 322-324.

SCHUSTER F.L. Cultivation of pathogenic and opportunistic freeliving amoebas. Clinical microbiology review, 2002, 15, 342-354.

Schuster F.L. \& Visvesvara G.S. Amoebae and ciliated protozoa as causal agents of waterborne zoonotic disease. Veterinary Parasitology, 2004, 126, 91-120.

Szenasi Z., Endo T., Yagita K. \& NAgy E. Isolation, identification and increasing importance of free-living amoebae causing human disease. Journal of Medical Microbiology, 1998, 47, 5-16

Tsvetkova N., Schild M., Kurdova-Mintcheva S.P.R., WalochNIK B.G.J., Aspock H. \& Muller M.S.L.N. The identification of free-living environmental isolates of amoebae from Bulgaria. Parasitology research, 2004, 92, 405-413.

Walochnik J., Hassl A., Simon K., Benyr G. \& Aspock H. Isolation and identification by partial sequencing of the $18 \mathrm{~S}$ ribosomal gene of freeliving amoebae from necrotic tissue of Basilliscus plumifrons (Sauria: Iguanidae). Parasitology Research, 1999, 85, 601-603.

Reçu le 26 juin 2006 Accepté le 27 janvier 2007 